\title{
EHRHARTA LONGIFLORA SM. AND PENNISETUM SETACEUM (FORSK.) CHIOV., TWO NEW ALIEN GRASSES FOR MADEIRA ISLAND (PORTUGAL)
}

\author{
Laura Cabral*, João Pedro Ferreira*, André Brazão* \\ Pedro Nascimento* \& Miguel Menezes de Sequeira**
}

\begin{abstract}
The number of introduced, and possible introduced, taxa in the Madeira and Selvagens islands currently accounts for nearly $36 \%$ of the total flora of these archipelagos, including 53 Poaceae taxa (out of 141 Poaceae taxa), therefore constituting the family with the higher proportion of introduced taxa (38.4\%). The genus Ehrharta Thunb. comprises about 35 species, with one species, E. longiflora Sm., recorded as introduced in Gran Canaria. The genus Pennisetum Rich. includes ca. 80 species of which a total of nine species are present in Macaronesia, with three: $P$. clandestinum Hochst. \& Chiov., P. purpureum Schum. and P. villosum R. Br. ex Fresen, occurring in the Madeira archipelago. Ehrharta longiflora Sm. and Pennisetum setaceum (Forssk.) Chiov., are here recorded for the first time for the Madeira island, found in disturbed areas at low and medium altitudes. The finding of several mature and flowering/fructifying individuals of both species suggests a fully naturalized status. Naturalization, invasiveness and ecological impacts are discussed.
\end{abstract}

Keywords: alien, Ehrharta longiflora, grasses, Madeira, Pennisetum setaceum.

EHRHARTA LONGIFLORA SM. Y PENNISETUM SETACEUM (FORSK.) CHIOV., DOS NUEVAS GRAMÍNEAS EXÓTICAS PARA LA ISLA DE MADEIRA (PORTUGAL)

\section{RESUMEN}

El número de taxones introducidos y posiblemente introducidos en los archipiélagos de Madeira y Salvajes supone aproximadamente un 36\% de su flora total, incluyendo 53 taxa de poáceas (sobre un total de 141 taxa de poáceas), constituyendo, de esta manera, la familia botánica con mayor número de taxa introducidos (38,4\%). El género Ehrharta Thunb. comprende unas 35 especies, con una especie, E. longiflora Sm., registrada como introducida en Gran Canaria. El género Pennisetum Rich. incluye cerca de 80 especies, de las cuales un total de nueve especies están presentes en Macaronesia, de las que tres ( $P$. clandestinum Hochst. \& Chiov., P. purpureum Schum. y P. villosum R. Br. ex Fresen), se encuentran en el archipiélago de Madeira. Ehrharta longiflora Sm. y Pennisetum setaceum (Forssk.) Chiov. se citan en este trabajo por primera vez para la isla de Madeira, donde han sido encontradas en áreas perturbadas a bajas y medias altitudes. El hallazgo de varios individuos maduros en estado de flor/fruto de ambas especies sugiere que están totalmente naturalizadas. El trabajo discute la naturalización, la capacidad invasora y los impactos ecológicos generados por las mismas.

Palabras Clave: especies exóticas, Ehrharta longiflora, gramíneas, Madeira, Pennisetum setaceum. 


\section{INTRODUCTION}

The archipelagos of Madeira and Selvagens include 1204 taxa of vascular plants, including 401 introduced taxa and 29 as possible introduced (Jardim and Menezes de Sequeira 2008). In what concerns the grass family, more than one third correspond to alien taxa, i.e. 54 out of 141 (Jardim and Menezes de Sequeira 2008), corresponding to almost $12 \%$ of the total number of introduced vascular plant taxa.

Pennisetum Rich. is a cosmopolitan tropical genus that includes about 80 species native from Africa (Fish et al. 2015). A total of 9 species of this genus are already reported in the Macaronesian archipelagos, 7 of them as aliens: Pennisetum atrichum Stapf ex Hubb. (Cabo Verde), Pennisetum clandestinum Hochst. ex Chiov. and Pennisetum villosum R. Br. ex Fresen. (Azores, Madeira archipelago and Canary Islands), Pennisetum purpureum Schumach. (Canary Islands and Madeira), Pennisetum setaceum (Forssk.) Chiov., Pennisetum thunbergii Kunth and Pennisetum glaucum (L.) R. Br. (Canary Islands) (Sánchez-Pinto et al. 2005; Jardim and Menezes de Sequeira 2008; Acebes Ginóves et al. 2009; Silva et al. 2010; Verloove 2013). There is also a reference to Pennisetum macrourum Trin. for the Canary Islands as cultivated and occurring spontaneous in one locality in Las Palmas (Reyes-Betancort et al. 1999).

The segregation of the genera Pennisetum and Cenchrus L. has always been controversial. Diagnostic morphological characters being the degree of fusion of bristles and their characteristics, and the presence of pedicellate spikelets, however none of these characters can fully differentiate them (Chemisquy et al. 2010). Although some authors still consider Pennisetum and Cenchrus as two separate genera (Fish et al. 2015), recent molecular studies suggest otherwise (Donadío et al. 2009). Chemisquy et al. (2010), also based on molecular data, propose the inclusion of both Odontelytrum Hack. and Pennisetum in the genus Cenchrus.

Pennisetum clandestinum, was included in a separate genus -Kikuyuochloa H. Scholz (Scholz, 2006), but included in Cenchrus by other authors (Verloove 2012; Veldkamp 2014). The taxonomic and nomenclatural criteria adopted here follow Jardim and Menezes de Sequeira (2008). Pennisetum setaceum native distribution ranges from North Africa to the Middle East (Fish et al. 2015). In Europe, it is

* Madeira Botanical Group (GBM), Faculty of Life Sciences, Universidade da Madeira, Funchal, Portugal. Corresponding author: lauramariana97@hotmail.com.

** Madeira Botanical Group (GBM), Faculty of Life Sciences, Universidade da Madeira, Funchal, Portugal. InBio, Research Network in Biodiversity and Evolutionary Biology, CIBIO-Azores, Portugal. 
present as alien species in the south of the Iberian Peninsula, Canary archipelago and Sicily (Valdés and Scholz 2009). In Portugal, P. setaceum is naturalized in Alto Alentejo (Bejarano et al. 2011), Algarve (Marchante et al. 2014), and Extremadura (Gullón 2017).

Pennisetum setaceum was introduced as ornamental plant in the Canary Islands in the 40's (Saavedra and Alcántara 2017) and found naturalized in different locations in the north of Tenerife in 1969 (Hansen 1970). It is currently present in all the islands of the archipelago, prevailing below $500 \mathrm{~m}$ a.s.l., affecting the coastal xerophytic scrub and the endemic communities dominated by Euphorbia canariensis L. and E. balsamifera Aiton (González-Rodríguez et al. 2010). P. setaceum also outcompetes native grasses (e.g. Hyparrhenia hirta (L.) Stapf, Aristida adscensionis (L.), and affects the native rupicolous flora (Elorza et al. 2004; González-Rodríguez et al. 2010; Anonymous 2014).

Due to its fast growth and high capacity to adapt to different habitat conditions (Elorza et al. 2004), P. setaceum was recently included on the List of Invasive Species of Union Concern (EU 2017). Previously, this species was also included in the Spanish Catalogue of Invasive Alien Species, what entails in the "prohibition generic possession, transport, trafficking and trade of live or dead specimens, their remains or propagules, including foreign trade" (Anonymous 2014). Despite the conservation concerns, $P$. setaceum continues to be cultivated in many regions as ornamental plant (Gullón et al. 2017).

The genus Ehrharta Thunb. includes about 35 species, naturally distributed from South Africa to Ethiopia and Yemen (Fish et al. 2015). Four species of this genus: E. calycina Sm., E. delicatula Stapf, E. erecta Lam. and E. longiflora Sm., are present in Europe and North Africa (Morocco and Tunisia) as alien species (Valdés and Scholz 2009). E. longiflora was reported for Gran Canaria as naturalized for the first time by Kunkel (1978), as probably escape from cultivation, in a medium altitude (650 $\mathrm{m}$ a.s.l.), moist and shady habitat. In fact, E. longiflora is a palatable species for cattle, known to have a high leaf production (Fish et al. 2015).

Here we present the first record of E. longiflora and P. setaceum for the archipelago of Madeira. Naturalization, invasiveness and ecological impacts of both species are also discussed.

\section{MATERIAL AND METHODS}

Collected specimens where stored in the herbarium of the University of Madeira and identified using descriptions and keys published by Kellogg (2015) and Fish et al. (2015). During fieldwork, 2018 and 2019, collection sites were briefly characterized including: the approximate number of individuals of both species, the dominant plant taxa, exposure, slope and altitude (Table 1). The distribution map (Figure 1) was produced using ArcGis online version E204CW. The two species occurred in disturbed areas highly exposed to the sun. Fully developed flowering and fructifying individuals of both species were found (Figures 2, 3, 4 and 5). 


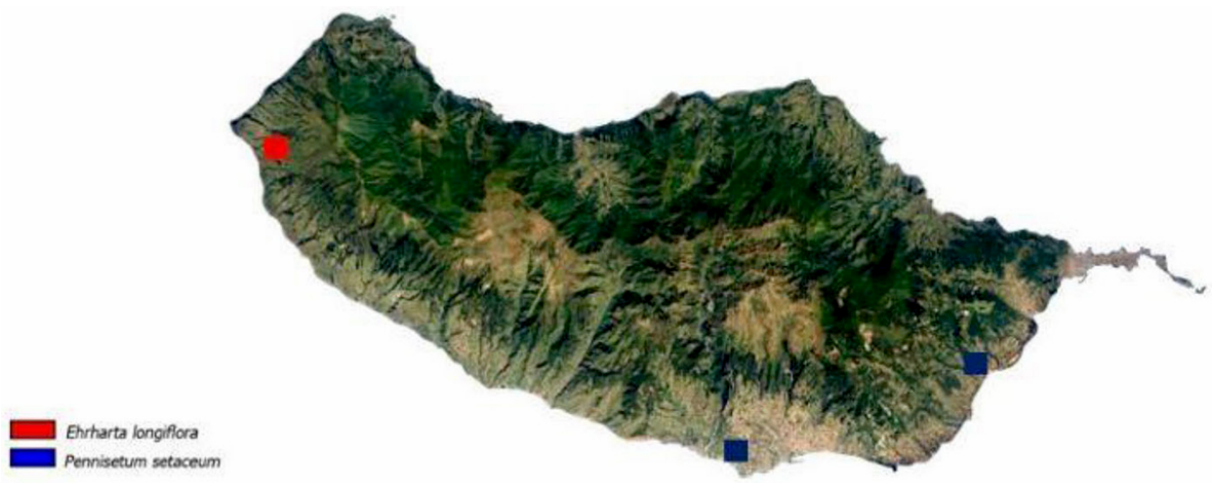

Figure 1. Distribution map of Ehrharta longiflora and Pennisetum setaceum.

\begin{tabular}{|c|c|c|c|}
\hline \multicolumn{4}{|c|}{$\begin{array}{l}\text { TABLE 1. DATA ON EHRHARTA LONGIFLORA AND } \\
\text { PENNISETUM SETACEUM MADEIRA POPULATIONS }\end{array}$} \\
\hline \multirow[b]{2}{*}{ Localities } & \multirow{2}{*}{$\begin{array}{c}\text { EHRHARTA LONGIFLORA } \\
\text { Ponta do Pargo }\end{array}$} & \multicolumn{2}{|c|}{ PENNISETUM SETACEUM } \\
\hline & & Santa Cruz & São Martinho \\
\hline Date of field work & May/June 2018 & August 2018/March 2019 & March 2019 \\
\hline Number of individuals & $<20$ & $>1000$ & 1 \\
\hline Dominant plant taxa & $\begin{array}{l}\text { P. clandestinum with } \\
\text { some individuals of } E \text {. } \\
\text { longiflora }\end{array}$ & $\begin{array}{l}\text { P. setaceum (in most of the } \\
\text { cases) and shared with } P \text {. } \\
\text { clandestinum, Ageratina } \\
\text { adenofora and Cardiosper- } \\
\text { mum grandiflorum }\end{array}$ & $\begin{array}{l}\text { Cenchrus ciliaris, Nicotiana } \\
\text { glauca, Sinapidendron agus- } \\
\text { tifolium, Parietaria sp. and } \\
\text { Rumex sp. }\end{array}$ \\
\hline Altitude/ altitude range & $568 \mathrm{~m}$ & 50 to $200 \mathrm{~m}$ & $15 \mathrm{~m}$ \\
\hline Slope & $30^{\circ}$ & Between $0^{\circ}$ and $90^{\circ}$ & $90^{\circ}$ \\
\hline Exposure & $\mathrm{N}$ & $\mathrm{S}$ and $\mathrm{O}$ & S \\
\hline Description & $\begin{array}{l}\text { Ruderal disturbed area } \\
\text { along a roadside, next to } \\
\text { agricultural land. High } \\
\text { exposition to the sun, } \\
\text { but with some humidity. }\end{array}$ & $\begin{array}{l}\text { Ruderal disturbed area } \\
\text { near a brook. Roads, } \\
\text { houses and gardens } \\
\text { nearby. High exposition to } \\
\text { the sun. }\end{array}$ & $\begin{array}{l}\text { Rocky cliff near the ocean, } \\
\text { next to a pedestrian path. } \\
\text { No gardens nearby. }\end{array}$ \\
\hline $\begin{array}{l}\text { Collector Number/ } \\
\text { UMad }\end{array}$ & JF150 & LC181 & - \\
\hline
\end{tabular}

\section{RESULTS}

\subsection{Pennisetum setaceum (Forsk.) Chiov}

Two populations of Pennisetum setaceum are here reported: one in St. Cruz (NE of Funchal) and another in Funchal, both at low altitude (Figure 1). Individuals of Pennisetum setaceum found in St. Cruz formed dense tuffs, mostly on terrains near 


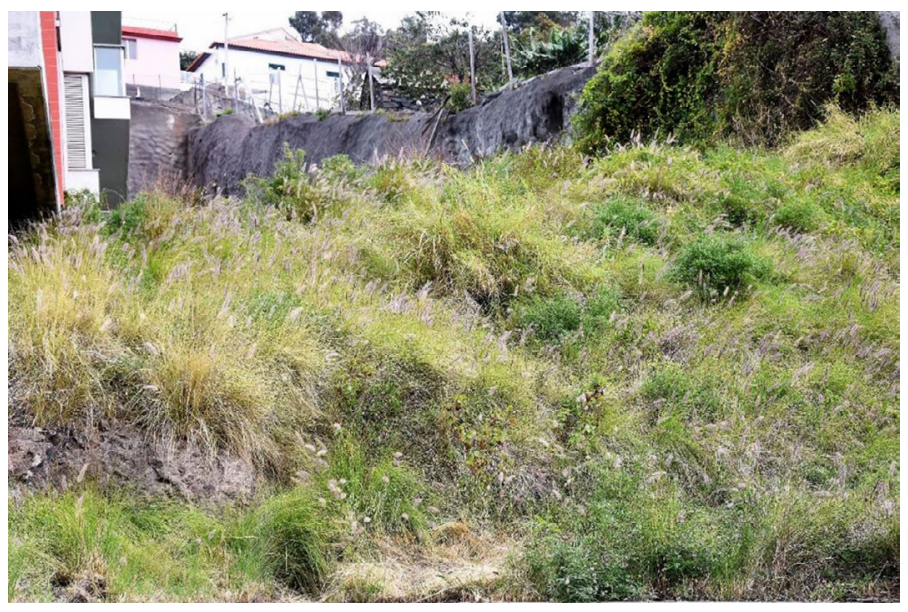

Figure 2. Pennisetum setaceum individuals forming dense tuffs on a terrain (St. Cruz).

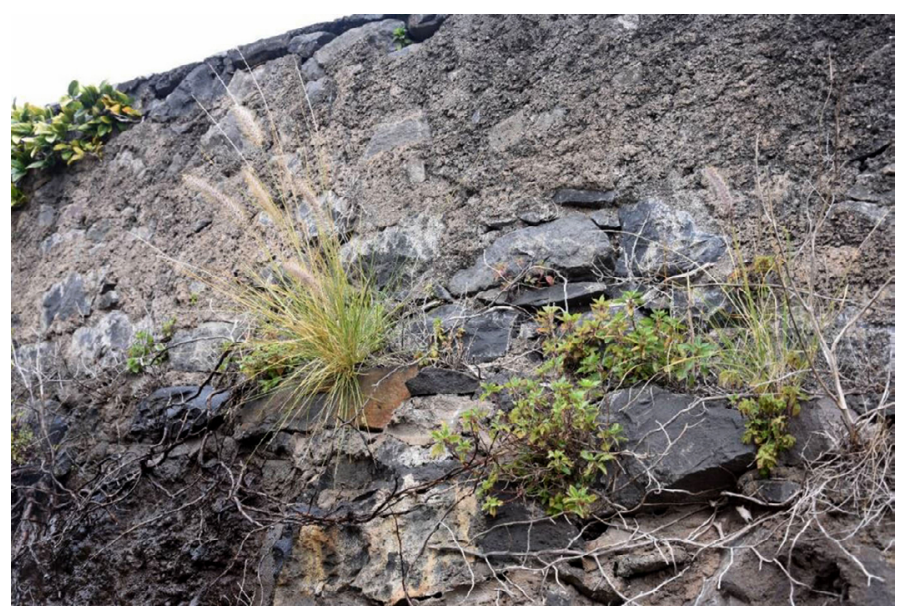

Figure 3. Pennisetum setaceum, individuals in a basaltic walls (St. Cruz).

a road (Figure 2), but also in cliffs and basaltic walls (Figure 3) including on a margin of a small brook, corresponding to highly hemerobic areas close to roads, houses and gardens. P. setaceum was the dominant plant, although this dominance was shared, in some cases, with other alien plants such as Pennisetum clandestinum, Ageratina adenophora (Spreng.) R.M. King \& H. Rob. and Cardiospermum grandiflorum Sw. Cosentinia vellea (Aiton) Tod. (Table 1), a rare native fern in Madeira island, was found in chasmophytic invaded habitats. 
One individual of Pennisetum setaceum was found on a cliff near the ocean in Funchal (São Martinho), next to a pedestrian path and with no gardens nearby, on a community dominated by Cenchrus ciliaris L., Nicotiana glauca R.C. Graham and Sinapidendron angustifolium (DC.) Lowe (table 1). After the first visit, the specimen was eventually removed, and no other individuals were found in the surrounding area.

Portugal, Madeira, Santa Cruz; near "Rua da Ribeira" street; on a terrain near houses and gardens; 32 $41^{\prime} 23.07^{\prime \prime} \mathrm{N}$; 1647’44.39”W; alt. ca. $50 \mathrm{~m}$ a.s.l., 06-VII2018, Laura Cabral, LC181, UMad s/n;

Based on Cope (1994), Veldkamp (2014) and Clayton (1980), we suggest a new key for the identification of Pennisetum species presents on Madeira archipelago. Pennisetum Rich. key to the Madeira archipelago species:

1- Culms mat-forming, inflorescence reduced to a cluster of 2-4 subsessile spikelets enclosed in the uppermost sheath, with long protruding filaments and stigmas, involucral bristles soft P. clandestinum

1'- Culms erect to geniculate at base, inflorescence exerted, with many spikelets, involucral bristles stiff or softly villous.

2- Dwarf plant up to $20(-40) \mathrm{cm}$, with a broadly cylindrical to sub-globose inflorescence, spikelets $7-14 \mathrm{~mm}$, bristles softly villous. P. villosum

2'- Plants generally larger, with a narrowly cylindrical inflorescence, spikelets 4.5-7 $\mathrm{mm}$, bristles stiff.

3- Plant up to $6 \mathrm{~m}$ (reed like), leaf blades flat $16-150 \times 0.4-4 \mathrm{~cm}$ with spinulose margins, peduncle pilose below the inflorescence, involucre with one bristle distinctly longer than the others

P. purpureum

3'- Plants up to $2 \mathrm{~m}$, leaf blades involute 30-100 $\times 0.1-0.37 \mathrm{~mm}$, with scaberulous margins, peduncle glabrous below the inflorescence, involucre with a few bristles distinctly longer than the others

P. setaceum

\subsection{EHRHARTA LONGIFLORA SM.}

One population of E. longiflora was found in Calheta (Ponta do Pargo) (figure 1) along a roadside close to agriculture fields occupying, so far, a very restricted area, dominated by $P$. clandestinum (table 1 ). This population included several mature individuals (figures 4 and 5) suggesting a fully, although localized, naturalization. In June, one month after the first visit, plants were subject to mowing, therefore no photographs of the naturalization site were taken.

Portugal, Madeira, Calheta: Ponta do Pargo; along a roadside of "Estrada Regional 101", next to agricultural land; 3248'6.04”N; 17¹4'27.47’W; alt. ca. 568 $\mathrm{m}$ a.s.l., 12-V-2018, João Ferreira, JF150, UMad s/n. 


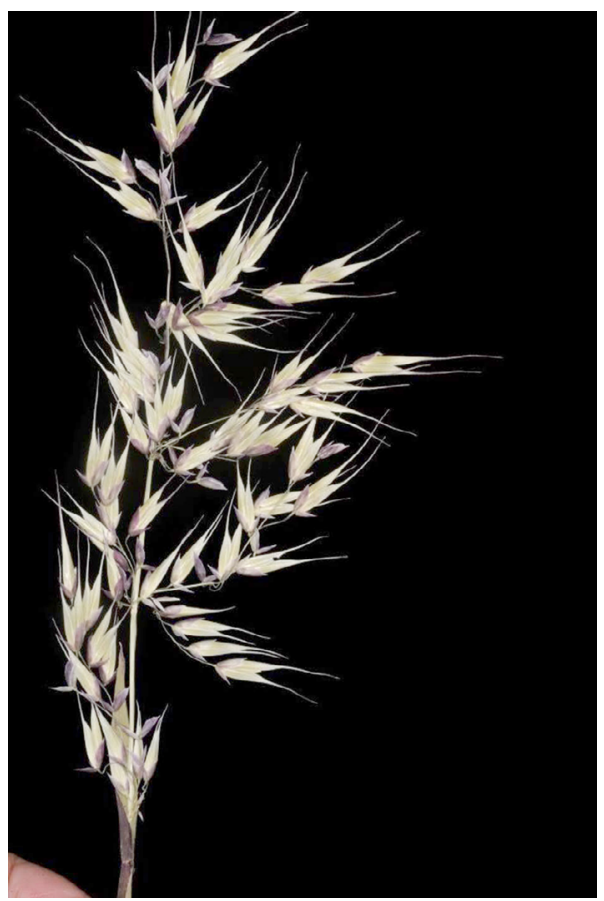

Figure 4. Ehrharta longiflora, panicle.

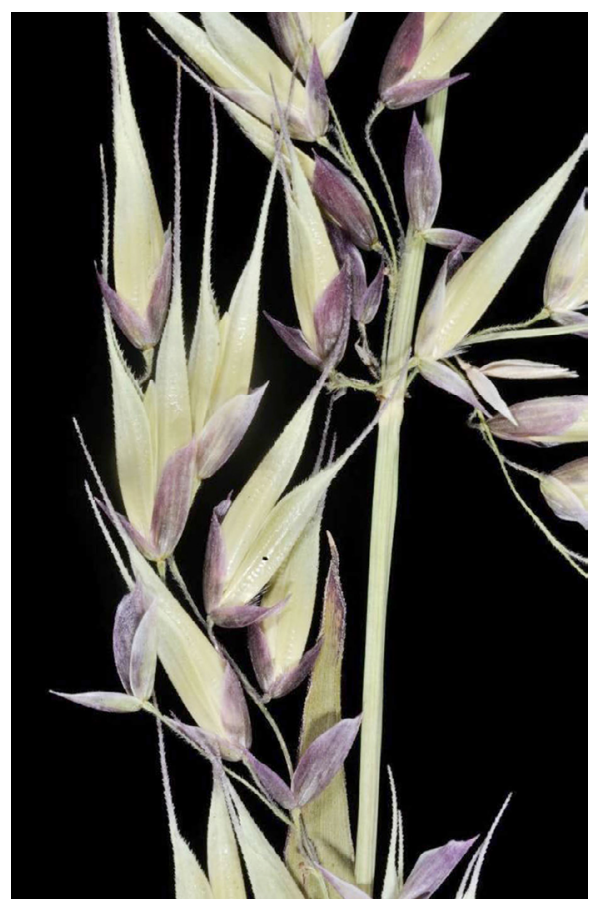

Figure 5. Ehrharta longiflora, detail of panicle.

\section{DISCUSSION}

Pennisetum setaceum was probably introduced in Madeira island as ornamental plant, considering that this species is used in many parts of the world for this purpose and is often found in nurseries (Salinas et al. 2011; Saavedra et al. 2014; GIDS 2015; Gullón et al. 2017). P. setaceum is a perennial C4 plant and, consequently, can withstand dryness and high temperatures, being widely used as garden plant (Rahlao et al. 2010). Sometimes, it is also used for the stabilization of soil and cliffs (Salinas et al. 2011). These characteristics, along with ecological adaptability, rapid growth and high seed production (100 seeds per plant), make it a species with high invasive potential (EPPO 2012).

So far Pennisetum setaceum has a relatively small area of distribution on Madeira island, but according to Dana et al. (2005) fruits are easily dispersed, by water, animals, people and even cars, being therefore highly probable that this alien grass will spread quickly to other areas. Salinas et al. (2011) also refer that fruits are easily dispersed and to the fact that fruits remain viable in the soil for 6 years or more, being also capable of sprouting from root fragments. 
Pennisetum setaceum prevails on arid and semi-arid open areas (ReyesBetancort et al. 1999; GISD 2015), and, therefore, Madeiran Mediterranean secondary grass communities (e.g. Dactylo hylodes-Hyparrhenietum sinaicae, Cenchro ciliaris-Hyparrhenietum sinaicae and Bromo-Oryzopsion miliacei, as defined by Capelo et al. 2004) could be invaded by this grass. If this invasion occurs, it will possibly block successional processes, therefore affecting endemic communities such as Euphorbietum piscatorie. P. setaceum will also potentially affect chasmophytic plant communities (e.g. Sedo nudi-Aeonietum glutinosi).

Salinas et al. (2011) describe the elimination by competition, of native and endemic species, but also changes in soil carbon sequestration, that further affect succession. In the Canary Islands P. setaceum can reach altitudes above $1000 \mathrm{~m}$ a.s.l. (Reyes-Betancort et al. 1999; Salinas et al. 2011), but it seems to be limited to areas with an average annual rainfall of less than $1270 \mathrm{~mm} / \mathrm{m}^{2}$ (GISD 2015), not tolerating freezing temperatures (Devender 1997). These data suggest that the south coast and the east side of the island of Madeira are likely to be invaded and that most of the north coast and the mountain areas are less likely to be affected.

Due to the large amount of biomass accumulated, $P$. setaceum potentiates the risk of fires, which further increases its expansion (Salinas et al. 2011).

Ehrharta longiflora was probably introduced for cattle feeding (see Fish et al. 2015), since it was found naturalized near agricultural fields. The dispersion of E. longiflora mainly occurs locally and is wind mediated, but fruits may also be dispersed by animals (Frey 2005). This species is already recorded as naturalized in several countries of North Africa and Europe, including Spain (Valdés and Scholz 2009) and being reported as invasive in Australia, New Zeeland and California (Frey 2005).

Ehrharta longiflora typically occurs in wet shady places (near rocks and shrubs), often near disturbed areas (e.g. gardens, roadsides), but is also found in hill slopes (Fish et al. 2015). Apparently, the invasion of this and other Ehrharta spp. is facilitated by moisture. Besides that, these species can tolerate extensive annual summers in Mediterranean climates due to their deep-roots (Frey 2005).

In Madeira, E. longiflora possibly will prevail in areas of medium altitude, such as occurs in the Canary Islands (Kunkel 1978), but its invasiveness is hard to predict due to the scarcity of available information. Irrigated disturbed areas could be at higher risk of invasion, but this species may disperse to areas of high conservation value, possibly including laurisilva clearings and margins.

As in the islands of El Hierro, La Gomera, Fuerteventura and Lanzarote, where the introduction of P. setaceum was later (in the 1990s) (Garcia-Gallo et al. 1999) and where control is still approachable, monitorization of populations and quick intervention (eradication) seems to be the best strategies and should be applied for Madeira. According with Garcia-Gallo et al. (1999) the removal of individuals, manually or using hoes, seems to be the most effective method of eradication of $P$. setaceum (and has been applied in many parts of the world). It is important to eliminate the floral parts first by carefully covering the inflorescences with plastic bags, and removing all root fragments and seeds that are present in the soil (GarciaGallo et al. 1999). Chemical methods may be implemented in situations where 
the complete removal of individuals is not possible (walls, asphalt) using systemic herbicides such as hexazinone or similar products, since glyphosate appears to be ineffective (Anonymous 2014).

Although both taxa may become troublesome invasive, Pennisetum setaceum constitutes a clear threat to Madeira ecosystems. P. setaceum is still in an initial phase of invasion and plants should be eradicated urgently, and its use as ornamental prohibited.

\section{ACKNOWLEDGMENTS}

The authors are grateful to the IFCN (Instituto das Florestas e Conservação da Natureza, IP-RAM) for the collecting permit (n. ${ }^{\circ}$ 05/IFCN/2017 - Flo Mad).

\section{AUTHORS' CONTRIBUTION}

Introduction: L.C., J.F.

Field work: L.C., J.F., P.N., A.B.

Methodologies: L.C., J.F., P.N., A.B., M.S.

Results and Discussion: L.C. J.F., P.N., A.B., M.S.

Review and edition of the final draft: M.S.

ReCibido: septiembre de 2019; ACEPTAdo: abril de 2020 


\section{REFERENCES}

Anonymous. 2014. Orden de 13 de junio de 2014, por la que se aprueban las Directrices técnicas para el manejo, control y eliminación del rabogato (Pennisetum setaceum) [Internet]. Boletín Oficial de Canarias núm. 120; [cited 2019 Feb 2]. Available from http://www.gobiernodecanarias.org/boc/.

Bejarano, A., Gutiérrez, A. and Vázquez, F.M. 2011. Aproximación al conocimiento de flora neófita en la cuenca del Guadiana Internacional a su paso por Extremadura (España) Alentejo (Portugal). Folia Bot. Extremadurensis 5: 5-29.

Capelo, J., Menezes De Sequeira, M., Jardim, R. and Costa, J.C. 2004. Guia da excursão geobotânica dos V Encontros ALFA 2004 à ilha da Madeira. In: Capelo, J.A. (ed.) Paisagem vegetal da ilha da Madeira. Quercetea 6: 5-45.

Clayton, W.D. 1980. Pennisetum and Cenchrus. In: Tutin, T.G., Heywood, V.H., Burges, N.A., Moore, D.M., Valentine, D.H., Walters, S.M. and Webb, D.A. (eds.). Flora europaea. Vol. 5. Alismataceae to Orchidaceae (Monocotyledones). Cambridge: Cambridge University Press 264 pp.

Cope, T.A. 1994. Poaceae. In: Press, J.R. and Short, M.J. (eds.) Flora of Madeira. London: The Natural History Museum pp. 404-452.

Dana, E.D., Sanz-Elorza, M., Vivas, S. and Sobrino, E. 2005. Especies vegetales invasoras en Andalucía. Sevilla: Consejería de Medio Ambiente 233 pp.

Devender, T., Felger, R. and Búrquez, A. 1997. Exotic Plants in the Sonoran Desert Region, Arizona and Sonora. Proceedings of the California Exotic Pest Plant Council Symposium 3: 10-15.

Elorza, M.S., SÁnchez, E.D. and Vesperinas, E.S. (eds.) 2004. Atlas de las Plantas Alóctonas Invasoras en España. Madrid: Dirección General para la Biodiversidad 384 pp.

EU (European Union). 2017. Commission implementing regulation (EU) 2017/1263 of 12 July 2017 updating the list of invasive alien species of Union concern established by Commission Implementing Regulation (EU) No 2016/1141 pursuant to Regulation (EU) No 1143/2014 of the European Parliament and of the Council. [Internet]; [cited 2019 Feb 2]. Available from http://eur-lex.europa.eu/legal-content/EN/TXT/?uri=CELEX:32017R1263.

Fish, L., Mashau, A., Moeaha, M. and Nembudani, M. 2015. Identification guide to southern African grasses. An identification manual with keys, descriptions and distributions. South African National Biodiversity Institute, Pretoria. Strelitzia 36: 19-628.

Frey, M. 2005. Element Stewardship abstract for Ehrharta spp. Thunb. (Including Ehrharta erecta Lam., Ehrharta calycina and Ehrharta longiflora Sm.) [Internet]. Mandy, T. and Martin, T. (eds.) The Nature Conservancy's Invasive Species Initiative; [cited 2018 Sep. 5]. Avaible from https://www.invasive.org/gist/esadocs/documnts/.

García-Gallo, A., Wildpret, W., Rodríguez, O., Pérez De Paz, P.L., León, M.C., Suárez, C. and Reyes-Betancort, J.A. 1999. El xenófito Pennisetum setaceum en las Islas Canarias (Magnoliophyta, Poaceae). Vieraea 27: 133-158.

Acebes Ginóves, J.R., Arencibia, M.C., Navarro, M.L., Del Arco, M.J., García-Gallo, A.G., Pérez De Paz, P.L., Rodríguez Delgado, O., Martín Osorio, V.E. and Wildpret, W. 2009. Pteridophyta, Spermatophyta. In: Arechavaleta, M.S., Rodríguez, S., Zurita, N. and García, A. (eds.). Lista de especies silvestres de Canarias. Hongos, plantas y animales terrestres. Consejería de Medio Ambiente y Ordenación Territorial, Gobierno de Canarias pp. 119-122. 
Global Invasive Species Database (GISD). 2015. Species profile Cenchrus setaceus. [cited 2019 Feb 19]. Available from http://www.iucngisd.org/gisd/species.php?sc=309.

Gullón, E.S., Verloove, F. and Silva, V. 2017. New records of interesting xenophytes in the Iberian Peninsula. VII. Folia Botanica Extremadurensis 11: 39-50.

González-Rodríguez, A.M., Baruch, Z., Palomo, D., Cruz-Trujillo, G., Jiménez, M.S. and Morales, D. 2010. Ecophysiology of the invader Pennisetum setaceum and three native grasses in the Canary Islands. Acta Oecol. 36: 248-254.

Hansen, A. 1970. Contributions to the Flora of the Canary Islands (especially Tenerife). Cuad. Bot. Canar. 9: 37-59.

Jardim, R. and Menezes de Sequeira, M. 2008. The vascular plants (Pteridophyta and Spermatophyta) of the Madeira and Selvagens archipelagos. In: Borges, P.A.V., Abreu, C., Aguiar, A.M.F., Carvalho, P., Jardim, R., Melo, I., Oliveira, P., Sérgio, C., Serrano, A.R.M. and Vieira, P. (eds.). A list of the terrestrial fungi, flora and fauna of Madeira and Selvagens archipelagos. Funchal and Angra do Heroísmo: Direcçao Regional do Ambiente da Madeira and Universidade dos Açores pp. 157-207.

Kellogg, E.A. 2015. The Flowering Plants Monocots: Poaceae. In: Kubitzki, K. (ed.) The families and genera of vascular plants. Springer International Publishing 13 pp. 129-333.

Kunkel, G. 1978. An Excursion through my herbarium-II. Vieraea 8: 337-364.

Marchante, H., Morais, M., Freitas, H. and Marchante, E. 2014. Guia prático para a identificação de Plantas Invasoras em Portugal. Coimbra: Imprensa da Universidade de Coimbra 25 pp.

Rahlao, S.J., Esler, K.J., Milton, S.J. and Barnard, P. 2010. Nutrient addition and moisture promote the invasiveness of crimson fountaingrass (Pennisetum setaceum). Weed Sci. 58: 154-159.

Reyes-Betancort, J., Arencibia, M. and García Gallo, A. 1999. Consideraciones acerca del género Pennisetum en Canarias (Magnoliophyta, Poaceae). Vieraea 27: 205-216.

Saavedra, M., Hidalgo, J.C., Hidalgo, J. and Alcántara, C. 2014. Pennisetum setaceum. Planta invasora con gran peligro potencial. Córdoba: Consejería de Agricultura, Pesca y Desarrollo Rural, Instituto de Investigación y Formación Agraria y Pesquera. [cited 2018 Sep 2018]. Available from http://www.juntadeandalucia.es/agriculturaypesca/ifapa/servifapa/contenidoAlf?id=4f4e2f29-c16d-4a84-b8d9-ble41d98d2d3\&rateParam=rateOk.

Saavedra, M. and Alcántara, C. 2017. Pennisetum setaceum, planta invasora en expansión. Proceedings of the XVI Congreso de la Sociedad Española de Malherbologia; Pamplona.

Salinas, M.J., López-Escoriza, A. and Cabello, J. 2011. Expansión de la especie vegetal invasora Pennisetum setaceum (Forssk.) Chiov en las zonas áridas y semiáridas del Levante Andaluz (provincia de Almería). Informe Técnico del Programa de Seguimiento de los Efectos del Cambio Global en Zonas Áridas y Semiáridas del Levante Andaluz (GLOCHARID). Centro Andaluz para la Evaluación y Seguimiento del Cambio Global.

Sánchez-Pinto, L., Leticia Rodríguez, M., Rodríguez, S., Martín, K., Cabrera, A. and Cármen Marrero, M. 2005. Pteridophyta, Spermatophyta. In: Arechavaleta, M., Zurita, N., Marreno, M.C. and Martín-Esquivel, J.L. (eds.). Lista preliminar de especies silvestres de Cabo Verde (hongos, plantas y animales terrestres). Consejería de Medio Ambiente y Ordenación Territorial, Gobierno de Canarias pp. 38-57.

Silva, L., Pinto, N., Press, B., Rumsay, F., Carine, M., Henderson, S. and Sjogren, E. 2005. Lista das plantas vasculares (Pteridophyta e Spermatophyta). In: Borges, P.A.V., Cunha, R., 
Gabriel, R., Martins, A.M.F., Silva, L. and Vieira, V. (eds.). A list of the terrestrial fauna (Mollusca and Arthropoda) and flora (Bryophyta, Pteridophyta and Spermatophyta) from the Azores. Horta, Angra do Heroismo-Ponta Delgada: Direcçao Regional Direccão Regional do Ambiente. Universidade dos Acores pp. 131-156.

VAldés, B. and Scholz, H. 2009. Poaceae (pro parte majore). Euro+Med Plantbase-the information resource for Euro-Mediterranean plant diversity; [cited 2018 Sep 4]. Available from http://ww2.bgbm.org/europlusmed/.

Veldkamp, J.F. 2014. A revision of Cenchrus incl. Pennisetum (Gramineae) in Malesia with some general nomenclatural notes. Blumea 59: 59-75.

Verloove, F. 2012. New combinations in Cenchrus (Paniceae, Poaceae) in Europe and the Mediterranean Area. Willdenowia 42: 77-78.

Verloove, F. 2013. New xenophytes from Gran Canaria (Canary Islands, Spain), with emphasis on naturalized and (potentially) invasive species. Collet. Bot. 32: 59-82. 